\title{
Evidence for the Safe Use of the Extract from the Brazilian Arnica, Solidago chilensis Meyen, in Primary Health Care
}

\author{
Angélica A. Mercandeli ${ }^{*}$, Geisilane P. Bessa ${ }^{*}$, Silas N. Ronchi ${ }^{*}$, Tatiana P. S. Segato ${ }^{*}$, Ary G. da Silva ${ }^{* \#}$ \\ Universidade Vila Velha, Rua Comissário José Dantas de Melo, Vila Velha, Brazil \\ Email: "arygomes@uvv.br
}

Received October 11, 2011; revised December 3, 2011; accepted December 16, 2011

\begin{abstract}
In Brazil, the National Policy on Medicinal Plants has stimulated the use of plants in primary health care, validating the traditional medicine and pointing to the lack of a consistent set of evidence that supports their uses and indications by ethnobotany and ethnopharmacology. This paper aims to make a systematic review of the scientific literature to gather evidence on indications and safety of use of extracts of Solidago chilensis. The bibliographic research was carried out using terms derivate from the title, and all the published papers were downloaded, covering at least the last five years, and it was focused on preclinical and clinical studies with extracts of $S$. chilensis in the databases of Web of Science, BIREME, SciELO, PubMed, Scirus and Highwire. Phytochemical analysis carried out on many studies showed that among the chemical constituents of S. chilensis are sesqui- and diterpenes, flavonoids and other substances, and the diterpene solidagenone was identified as a marker of the extract that has demonstrated gastroprotective activity in different experimental models of ulcer induced in animals without signs of toxicity at doses above $600 \mathrm{mg} / \mathrm{kg}$. Another studies show that the anti-inflammatory effect in rats has been given by inhibiting the exudation of leukocytes, especially neutrophils, as well as through inhibition of myeloperoxidase, adenosine deaminase, and tumor necrosis factor- $\alpha$ $(\mathrm{TNF}-\alpha)$, decreased induction of nitric oxide synthesis and levels of interleukin- $1 \beta$. Studies show that solidagenone at a concentration of $100 \mathrm{mg} / \mathrm{kg}$ showed activity similar to lansoprazole $(20 \mathrm{mg} / \mathrm{kg})$, the effect occurs without changes in the gastric mucosa or on acid secretion. The aqueous and alcoholic extracts showed anti-inflammatory activity and may act in a satisfactory way in cases involving the inflammatory response, such as injuries due to trauma, repetitive stress, pain, and healing. The inhibition of anti-inflammatory response is on the base of all these described effects. In spite of the fact that $S$. chilensis has been used since ancient times in Brazilian traditional medicine, and the existence of preclinical pharmacological end toxicological evidence for its efficacy as an inhibitor of anti-inflammatory response, we could find only a single clinical trial study carried out in treating lumbago. In this lack of clinical pharmacology and toxicology evidence for its uses, its safety and therapeutic indications are guaranteed, up to this moment, by traditional knowledge.
\end{abstract}

Keywords: Safe Use; Primary Health Care; Traditional Knowledge; Anti-Inflammatory

\section{Introduction}

Despite the diversity of drugs developed by pharmaceutical industry, the traditional indigenous herbal medicine is still practiced in many Brazilian rural areas as therapeutic practices in primary health care. The World Health Organization (WHO) has emphasized the importance of indigenous traditional medicine since, in most rural areas of developing countries still using these drugs as first choice in health care and thus, building a history of traditional use of medicinal plants $[1,2]$.

\footnotetext{
"Authors' Contributions: AGS designed the study. AAM, GPB, TPSS, SNR and AGS organization and adequacy of the data submission standards. All authors contributed actively in the literature necessary for the construction of this manuscript and all authors read and approved the final manuscript.

"Corresponding author.
}

Considering the widespread use of medicinal plants in Brazilian folk medicine, they are currently objects of many researches on the search for evidence for their therapeutic use. There is a wide use of these plants in Brazil as complementary health treatments, as a consequence of the high Brazilian biodiversity indexes that make traditional communities in close contact with natural resources [3]. Brazilian National Policy for medicinal plants and phytomedicines validated and stimulated the use of those traditionally known medicinal plants in primary health care [4]. In the context of that policy, from which the National Program of Medicinal Plants was derived, a trend in investigations was established, leading the phytomedicine practice to include the traditional knowledge as an important argument not only for the use of plants in primary health care [5], but also for the official registry of phytomedicines in Brazilian Ministry of Health [6]. 
Among the plants used in Brazilian traditional Medicine, the name "arnica" became popular after the arrival of European immigrants, principally the Italians, at the end of the 19th century. These new settlers gave this name to the plants they encountered in Brazil that had aromas similar to that of Arnica montana L., that grew in Europe, and that will be nominated, from now on, as European arnica [7,8]. Despite of the fact of not always adequate or successful, early European immigrants sought correspondence between Brazilian native plants and the Old World species that they had been familiar with. This gave rise to the identification of various Brazilian "arnicas" that were recognized for their analgesic and anti-inflammatory properties [8].

One of the Brazilian arnicas, Solidago chilensis Meyen, belongs to the family Asteraceae [9]. This herb had already received another binomial name that is now taken as nomenclatural synonym for the former one, Solidago microglossa DC, and under that name it took part of the 1st edition of Brazilian Pharmacopeia [10] for its antiseptic, analgesic, and healing properties [11]. This plant is also referred as "arnica-do-campo" [12] and "erva-lanceta" [13]. The uses attributed it include treating rheumatic and lumbar pain, contusions, wounds, and inflammations caused by insect bites [14,15]. From now on it will be here referred in this paper as Brazilian arnica.

The investigation of phytochemical constituents from S. chilensis revealed the presence of flavonoids and saponins, substances known by their anti-inflammatory, antiespasmolitic and antidiuretic effects. However, there are few evidence on those pharmacological properties for this phytomedicine, that were produced through clinical trials [16]. So, this paper aims to make a systematic review on the preclinical and clinical evidence for the use of the $S$. chilensis in inflammatory processes.

\section{Traditional Clinical Indications of Uses of Solidago chilensis}

Some indigenous communities, for example, the Mapuche, who live in arid Patagonia (Argentina) use this herb for medicinal and edible use for subsistence $[17,18]$. In Brasil, its use as a substitute for the specie European arnica $A$. montana seems to be due to their similar pharmacological effect, particularly for the treatment of infections and inflammation, such as chronic nephritis, cystitis, urolithiasis and rheumatism [19,20]. In addition, its fresh rhizomes are used as a diuretic, appetite stimulant, anthelmintic and aerial parts as anti-inflammatory [21].

This species has medicinal properties indications as antispasmodic, anti-hemorrhagic, anti-inflammatory, antirheumatic beckic, bitter, stomachic, toothache, vulnerary, and is also indicated for bruising, swelling, sores, weakness of joints, bruises, rheumatism, trauma and varicose veins [2]. Also assigned by the taxonomic synonym $\mathrm{S}$. microglossa [22], this species properties as anti-inflammatory, analgesic, antirheumatic, and anti-hemorrhagic. It was placed in the second group of plants known and used by most pharmacists [23]. Its topical use is indicated in injuries, bumps, sprains, strains, bruises, falls, swelling, pain, trauma, among others [24] and is externally used as a substitute for A. montana to treat those illnesses [25]. The indication of the leaves of this species also can be done as a stimulant to gastro-intestinal wound healing and as anti-inflammatory agent [26].

However, this wide range of medicinal uses that arise from the traditional knowledge has not always been supported by preclinical or clinical evidence.

\section{Preclinical Trail Evidence}

Some pharmacological studies had demonstrated the gastroprotective effect of solidagenone in induced lesions in mouse models, in which some of its derivatives showed a statistically significant effect and reduction in lesion indices [27]. These effects seem to act through different and complementary mechanisms, many of them exhibit as a common characteristic, the stimulation of mucosal defensive factors and the modulation of the aggressive ones [28,29].

Other studies on gastroprotective activity showed that the terpenes and its derivatives from $S$. chilensis are effective in different experimental models of induced ulcer in animals without signs of toxicity at doses above 600 $\mathrm{mg} / \mathrm{kg}$. In addition, solidagenona at a concentration of $100 \mathrm{mg} / \mathrm{kg}$ showed activity similar to lansoprazole (20 $\mathrm{mg} / \mathrm{kg}$ ), the effect occurs without changes in the gastric mucosa or on acid secretion [30].

Several studies have shown that, due to the phytochemicals from Solidago species, they seem to possess anti-inflammatory properties, emerging at this point several possibilities to understand the mechanism of action of the extract of $S$. chilensis. Since its phytochemicals are bioavailable in the tissue layers beneath the skin and considering that both pain and inflammation have autacoids such as prostaglandins in their mediation, they may be involved in a common mechanism of action [27].

Anti-inflammatory effects and the mechanism of action of the glycolic extracts obtained from rhizomes, leaves and inflorescences of $S$. chilensis inhibited leukocytes, neutrophils and exudation in the mouse model of pleurisy in the inflammation induced by carrageenan. They also inhibited myeloperoxidase, adenosine-deaminase, and tumor necrosis factor alpha (TNF- $\alpha$ ), and induced decreasing in the nitric oxide, and interleukin- $1 \beta$ levels, demonstrating an important anti-inflammatory effect, inhibiting cells infiltration and also decreasing pro-inflammatory mediators release into the site of the inflammatory process [31]. 


\section{Evidence for the Use of Solidago chilensis in Primary Health Care}

The fluid glycolic extract of S. chilensis was effective in treating lumbago and increasing lumbar flexibility when compared to a placebo treatment. The significant improvements observed indicated that the phytochemicals present in the extract were able to satisfactorily permeate the skin. The results obtained contribute to the evaluation of $S$. chilensis as a medicinal plant useful in the treatment of lumbago [32].

The properties reported to $S$. chilensis have been considered as consequences of its phytochemical constituents, such as flavonoids, phenolics, acetophenone, carotenoid, glycosides, essential oil, saponins, terpenes, lactones, and the dihydro-helenalin helenalin, which are the most studied anti-phlogistic lactones [33], among other active constituents [34].

Cyclooxygenase 2-dependent prostaglandin E2 (COX2/ PGE2) is one of the important mediator abundantly produced in injured nerves and involved in the genesis of neuropathic pain. There are some novel proposed mechanisms underlying the role of COX2/PGE2 in injured nerves in the genesis of neuropathic pain. Long lasting COX2/PGE2 in injured nerves may induce chronic effects on nociceptors to facilitate the synthesis of painrelated molecules by stimulating injured or spared axons. COX2/PGE2 may also induce chronic effects on local inflammatory cells in injured nerves to facilitate the synthesis of inflammatory mediators via autocrine and paracrine pathways [35].

Prostaglandins are not the only inflammation mediators that have been involved in pain. The interleukin IL-1 $\beta$ is a pro-inflammatory cytokine has been implicated in pain, inflammation and autoimmune conditions that have been involved in various pain states, including the role of the intracellular complex, the inflammasome, which regulates IL- $1 \beta$ production. There are evidence of the importance of IL-1 $\beta$ in both in the induction and in the maintenance of pain in chronic states. Taken together, evidence of the importance of IL-1 $\beta$ in animal and human pain states, suggests that blockade of IL- $1 \beta$ be considered as a therapeutic opportunity [36].

Extracts of $S$. chilensis has a significant anti-inflammatory action on acute inflammatory responses and that its inhibitory activity may be due not only to the inhibittion of pro-inflammatory mediators, but also to the inhibition of leucocyte infiltration [31,37]. These facts make clear that the use of $S$. chilensis can come to contribute to the reversal of the inflammatory process thereby reverse frames of morbidity.

These facts points to a probable mechanism for the action of the extract of $S$. chilensis. If the phyto-pharmaceutically active substances from this species can be are into the tissues below the skin, and if the pain as well as the inflammation have common mediators $[32,35,38]$, it is possible that these compounds may act by controlling the mediators synthesis or accumulation, and that the extracts have anti-inflammatory activity, as indicated by ethnobotanical studies [15].

A marker of the extract of $S$. chilensis is the solidagenone, a labdane diterpene that was isolated from ethanol: ethyl ether extract seems to be one of those responsible for anti-inflammatory activity and gastroprotective, thus presenting a yield of $6.56 \%$ from the extract obtained from a mixture of ethyl ether: ethanol (1:1), also showing the immunomodulatory effect through its property of inhibition of nitric oxide in peritoneal macrophages of BALB/C [21].

Caffeoylquinic acid derivatives, one of the major components of $S$. chilensis hydroalcoholic extract have also been found in polar extract of the roots of another species known as Brazilian "arnica do cerrado", Lychnophora ericoides Mart. (Asteraceae) likewise demonstrated analgesic effects (when administered orally), with the markers 3,5-di-O-[E]-caffeoylquinic, 4,5-di-O-[E]- caffeoylquinic, and 3,4,5-[E]-tri-O-caffeoylquinic. They demonstrated significant analgesic activity in skin scarification tests induced by acetic acid [39].

Since that the phytochemicals present in the extract are able to satisfactorily permeate the skin [32], it can be inferred that extracts of Solidago can be applied in cases of healing, and that for it to occur it is necessary the presence of various cytokines and cells that make use of inflammatory process for tissue reconstruction [40].

\section{Conclusions}

The phytochemical analysis of $S$. chilensis allows us to affirm the potential of this plant on the anti-inflammatory for acting in the cells and markers of inflammatory response. These factors are likely to affirm the potential gastroprotective widely cited in this manuscript as well as its effect on wound healing and analgesia.

In spite of the fact that $S$. chilensis has been used since ancient times in Brazilian traditional medicine, and the existence of preclinical pharmacological end toxicological evidence for its efficacy as an inhibitor of anti-inflammatory response, we could find only a single clinical trial study carried out in treating lumbago. In this lack of clinical pharmacology and toxicology evidence for its uses, its efficacy and safety is up to this moment guaranteed by traditional knowledge.

\section{Acknowledgements}

The authors thanks the biologist Roy Funch for the English version and its revision, FUNADESP for A.G. Silva's Research Grant. 


\section{REFERENCES}

[1] E. L. Ratera and M. O. Ratera, "Plantas de la Flora Argentina Empleadas en Medicina Popular," Hemisferio Sur, Buenos Aires, 1980.

[2] J. R. Alonso, "Tratado de Fitomedicina Bases Clínicas y Farmacológicas," ISIS Editiones, Buenos Aires, 2004.

[3] M. C. T. Duarte and G. M. Figueira, "Anti-Candida Activity of Essential Oils and Extracts from Native and Exotic Medicinal Plants Used in Brazil," The Haworth Press Inc., 2004.

[4] Política Nacional de Plantas Medicinais e Fitoterápicos. http://bvsms.saude.gov.br/bvs/publicacoes/politica_nacio nal_fitoterapicos.pdf

[5] Programa Nacional de Plantas Medicinais. http://portal.saude.gov.br/portal/arquivos/pdf/politica_pla ntas_medicinais_fitoterapia.pdf

[6] Diário Official da União, "Agência Nacional de Vigilancia Sanitária," Dispõe Sobre Registro de Fitoterápicos, 2010, pp. 85-87.

[7] R. F. Vieira, "Conservation of Medicinal and Aromatic Plants in Brazil," In: J. J. Alexandria, Ed., Perspectives on New Crops and New Uses, ASHS Press, 1999, pp. 152-159.

[8] S. Miguel, "A Arnica Desvendada," Jornal da USP, Vol. 22, 2007, pp. 22-26.

[9] P. Weyerstahl, H. Marschall, C. Christiansen, D. Kalemba and J. Góra, "Constituents of the Essential Oil of Solidago canadensis ("Goldenrod") from Poland-A Correction," Planta Medica, Vol. 59, No. 3, 1993, pp. 281-282. doi:10.1055/s-2006-959673

[10] R. A. D. Silva, "Arnica Silvestre," Graphic Industry, São Paulo, 1929.

[11] A. S. C. Borges, "Efeito do Extrato de Solidago microglossa DC Sobre a Dissolução de Coágulos e a Hidrólise de N $\mu$-Benzoil-D, L-Arginina-Para-Nitroanilida," M.Sc. Dissertation, Federal University of Uberlândia, Uberlândia, 2001.

[12] V. Maioli-Azevedo and V. S. Fonseca-Kruel, "Plantas Medicinais e Ritualísticas Vendidas em Feiras Livres No Município do Rio de Janeiro, RJ, Brasil, Estudo de Caso nas zonas Norte e Sul," Acta Botanica Brasilica, Vol. 21, No. 2, 2007, pp. 263-275. doi:10.1590/S0102-33062007000200002

[13] G. Guarim-Neto and R. G. Morais, "Recursos Medicinais de Espécies do Cerrado de Mato Grosso, um Estudo Bibliográfico," Acta Botanica Brasilica, Vol. 17, 2003, pp. 561-584.

[14] C. E. T. Parente and M. M. T. Rosa, "Plantas Comercializadas Como Medicinais no Município de Barra do Piraí, RJ," Rodriguésia, Vol. 52, 2001, pp. 47-59.

[15] A. G. Christo, R. R. Guedes-Bruni, et al., "Uso de Recursos Vegetais em Comunidades Limítrofes à Reserva Biológica de Poço das Antas, Silva Jardim, RJ, Estudo de caso na Gleba Aldeia Velha," Rodriguesia, Vol. 57, 2006, pp. 519-542.

[16] P. Apáti, P. J. Houghton, G. Kite, G. B. Steventon and A. Kéry, "In Vitro Effect of Flavonoids from Solidago canadensis Extract on Glutathione Transferase," Journal of Pharmacy and Pharmacology, Vol. 58, No. 2, 2006, pp. 251-256. doi:10.1211/jpp.58.2.0013

[17] A. H. Ladio and M. Lozada, "Edible Wild Plant Use in a Mapuche Community of Northwestern Patagonia," $\mathrm{Hu}$ man Ecology, Vol. 28, No. 1, 2000, pp. 53-71. doi:10.1023/A:1007027705077

[18] D. Estomba, A. Ladio and M. Lozada, "Medicinal Wild Plant Knowledge and Gathering Patterns in a Mapuche Community from North-Western Patagonia," Journal of Ethnopharmacology, Vol. 103, No. 1, 2006, pp. 109-119. doi:10.1016/j.jep.2005.07.015

[19] R. Hänsel, K. Keller, H. Rimpler and G. Scheider, "Hagers Handbuch der Pharmazeutischen Praxis," Springer, Berlin, 1994.

[20] M. Blumenthal, W. R. Busse and A. Goldberg, "The Complete German Commission e Monographs," American Botanical Council, Austin and Integrative Medicine Communications, Boston, 1998.

[21] M. Soares, T. C. B. Tomassini, P. H. Leda, J. F. O. Costa and R. R. Santos, "Solidago chilensis Meyen-Solidagenona Como Agente Imunomodulador," XXVI Congresso Latino Americano de Química, Salvador, 2004.

[22] M. P. Corrêa, "Dicionário das Plantas Úteis do Brasil e das Exóticas Cultivadas," Ministério da Agricultura, Brasília, 1984.

[23] R. A. Moreira, et al., "Interest of Pharmaceutical Involved in Dispensing, for Medicinal Plants and Herbal Medicine," Infarma, Vol. 3-4, 2001, pp. 72-75.

[24] E. E. Sanguinetti, "Plantas que Curam," Rigel, Porto Alegre, 1989.

[25] H. Lorenzi and F. J. A. Matos, "Plantas Medicinais No Brasil, Nativas e Exóticas," Instituto Plantarum de Estudos da Flora, Sao Paulo, 2002.

[26] A. F. Morel, G. O. Dias, C. Porto, et al., "Antimicrobial Activity of Extractives of Solidago microglossa," Fitoterapia, Vol. 77, No. 6, 2006, pp. 453-455. doi:10.1016/j.fitote.2006.05.006

[27] G. Schmeda-Hirschmann, J. Rodriguez and L. Astudillo, "Gastroprotective Activity of the Diterpene Solidagenone and Its Derivates on Experimentally Induced Gastric Lesions in Mice," Journal of Ethnopharmacology, Vol. 81, No. 1, 2002, pp. 111-115. doi:10.1016/S0378-8741(02)00054-5

[28] D. A. Lewis and P. J. Hanson, "Antiulcer Drugs of Plant Origin," Progress in Medicinal Chemistry, Vol. 28, 1991, pp. 210-229. doi:10.1016/S0079-6468(08)70365-5

[29] C. A. Hiruma-Lima, R. C. Spadari-Bratfisch, D. M. GrassiKassisse and A. R. Brito, "Antiulcerogenic Mech- anisms of Dehydro-Crotonin, a Diterpene Lactone Obtained from Croton cajucara," Planta Medica, Vol. 65, No. 4, 1999, pp. 325-330. doi:10.1055/s-1999-13995

[30] I. Razmilic and G. Schmeda-Hirschmann, "Activity of Solidagenone and Their Semisynthetic Derivatives on the Glucocorticoid-Mediated Signal Transduction," Planta Medica, Vol. 66, 2000, pp. 86-88.

[31] S. Goulart, M. I. Moritz, K. L. Lang, R. Liz, E. P. Schen- 
kel and T. S. Fröde, "Anti-Inflammatory Evaluation of Solidago chilensis Meyen in a Murine Model of Pleurisy," Journal of Ethnopharmacology, Vol. 113, No. 2, 2007, pp. 346-353. doi:10.1016/j.jep.2007.07.003

[32] A. G. Silva, C. P. G. Sousa, et al., "Evaluation of an Extract of Brazilian Arnica (Solidago chilensis Meyen, Asteraceae) in Treating Lumbago," Phytotherapy Research, Vol. 24, 2010, pp. 283-287.

[33] R. Liz, S. V. G. Vigil, et al., "The Anti-Inflammatory Modulatory Role of Solidago chilensis Meyen in the Murine Model of the Air Pouch," Journal of Pharmeuticals and Pharmacology, Vol. 60, No. 4, 2008, pp. 515521. doi:10.1211/jpp.60.4.0015

[34] L. M. B. Torres, "Estudo Químico da Espécie Solidago microglossa DC," Ph.D. Thesis, São Paulo University, São Paulo, 1985.

[35] W. Ma and R. Quirion, "Does COX2-Dependent PGE2 Play a Role in Neuropathic Pain?" Neuroscience Letters, Vol. 437, No. 3, 2008, pp. 165-169.

doi:10.1016/j.neulet.2008.02.072
[36] K. Ren and R. Torres, "Role of Interleukin- $1 \beta$ during Pain and Inflammation," Brain Research Reviews, Vol. 60, No. 1, 2009, pp. 57-64. doi:10.1016/j.brainresrev.2008.12.020

[37] I. H. Hall, C. O. Starnes, K. H. Lee and T. G. Waddell, "Mode of Action of Sesquiterpene Lactones as Anti-Inflammatory Agents," Journal of Pharmaceutical Sciences, Vol. 69, No. 5, 1980, pp. 537-543. doi:10.1002/jps.2600690516

[38] S. Omoigui, "The Biochemical Origin of Pain, the Origin of All Pain Is Inflammation and the Inflammatory Response. Inflammatory Profile of Pain Syndromes," Medical Hypotheses, Vol. 69, No. 6, 2007, pp. 1169-1178. doi:10.1016/j.mehy.2007.06.033

[39] M. D. Santos, L. Gobbo-Neto, L. Albarella, G. Souza and N. P. Lopes, "Analgesic Activity of Di-Caffeoylquinic Acids from Roots of Lychnophora ericoides (Arnica da Serra)," Journal of Ethnopharmacology, Vol. 96, 2005, pp. 545-549.

[40] A. Shai and H. I. Maibach, "Diagnosis and Therapy. The Practical Approach,” Marion Philipp, Germany, 2005. 